\title{
Genetic Protective Role of D-Glucan against \\ Oxidative Stress Induced by Mitomycin and Gamma-Radiation Exposure in Male Albino Rats
}

\author{
M. M. Ahmed, N. M. El Beih* and S. A. Montaser
}

Radiation Biology Dept., National Centre for Radiation

Research and Technology (NCRRT), P. O. Box: 29 Nasr City,

Egypt. *zoology Dept., Faculty of Science, Ain Shams University.

\begin{abstract}
$\mathrm{D}$ GLUCAN is a polysaccharide with multi-branching molecules derived from the cell wall of baker's yeast. It was reported to modulated innate immunity via interaction with membrane receptors on macrophages, neutrophils and natural killer cells and posses potent antioxidant and free radical scavenging capabilities.

The aim of the present study was to investigate chemoprotective and radio-protective effect of D-glucan. Rats were orally (gavages) injected with D-glucan at dose of $(20 \mathrm{mg} / \mathrm{kg}$ body wt) daily for three weeks. Mitomycin c (MMC) was administered three equal doses $(1.5 \mathrm{mg} / \mathrm{kg}$ ) day after day for one week ( $2^{\text {nd }}$ week) before radiation exposure at 3 fractionated doses ( 2 Gy) day after day in the $2^{\text {nd }}$ week. The investigation were carried out on the days $3 \& 10$ post radiation-exposure and MMC administration for the determination of bone marrow micronucleus $(\mathrm{Mn})$ frequency and DNA fragmentation in blood lymphocytes.

The results showed that the exposure of animals to MMC and/ or irradiation led to clearly defined DNA fragmentation. D-glucan administration resulted in a significant improvement in lymphocytes DNA fragmentation and amelioration of Mn frequencies at day 3 and more pronounced at day 10 post irradiation. This study indicates that D-glucan has radio and chemo-protective effects against oxidative stress as a result of $\gamma$-radiation and/ or MMC exposure. So, D-glucan may be used to reduce the genotoxicity effects of different anticancer drugs and to reduce their unwanted side effects.

Keywords: D-glucan, $\gamma$-rays, mitomycin, DNA, micronucleus.
\end{abstract}

Anticancer drugs used in chemotherapy for tumors and leukemias inhibit proliferation and induce cell death in malignant cells. In addition to is effect, chemotherapy causes sever toxicity in normal cells leading to side effects such as mucositis, hair loss, and myelosuppression (Stahnke et al., 2001). 
MMC is one of the most common alkaloids, acting as an antineoplastic agent used to fight a number of different cancers including cancer of the stomach, colon, rectum, pancreas, breast, lung, uterus, cervix, bladder, head, neck, eye and esophagus. It is a potent DNA cross-linker (Siddique et al., 2005). On the other hand ionizing radiation used as radiotherapy which may be used as the primary therapy. It is also common to combine radiotherapy with surgery and / or chemotherapy and/or hormone therapy (Mussari et al., 2006). Facing is role, consequence of ionizing radiation exposure could be very serious including DNA damage, micronucleus formation and reduced cell viability (Shmakova et al., 2006 and Sterpone and Renata, 2010). One of the approaches to deal with these problems is to search for suitable anti-mutagens. Over last few years, much attention has been paid to the research of naturally occurring agents that are able to stimulate defence mechanisms of the organism against different oxidative stresses (Bobeck and Calbavy, 2001).

D-glucans consist of linear unbranched polysaccharides of $\beta$-D-Glucose like cellulose, but with one $1 \beta \rightarrow 3$ linkage for every three or four $1 \beta \rightarrow 4$ linkages. D-glucans form long cylindrical molecules containing up to about 250,000 glucose units. D-glucans occur in the bran of grains such as barley and oats, and they are recognized as being beneficial for reducing heart disease by lowering cholesterol and reducing the glycemic response (Chen and Seviour, 2007). According to the free-radical scavenging ability of glucan, no controversial occurred with the anti-tumour activity of the drugs. Moreover, it has been reported that glucan helps in reducing the side effects of conventional chemotherapy and radiotherapy, while at the same time enhancing its effectiveness (Tohamy et al., 2003).

DNA damage caused by ionizing radiation is manifested by single-and double-strand breaks in the sugar phosphate backbone of the DNA molecule, cross-links between DNA strands and also with chromosomal proteins (Dizdaroglu, 1992). Treatment with MMC induces DNA cross-links damage through adding methyl group to guanines in tracts of DNA which leads to inhibition of its replication (Tomasz et al., 1987). Selective removal of aziridine function of MMC results in a switch from minor to major groove alkylation of DNA (Nishiyama et al., 1997). Chen and Seviour (2007) and Tohamy et al. (2003) studied the mitotic index and Mn frequency after administration of

Egypt. J. Rad. Sci. Applic., Vol. 26, No. 1-2 (2013) 
chemotherapy, their results demonstrated that chemotherapy is a strong chemical agents that can bind and chelate DNA causing its replication inhibition through chromosomal breaks, which resulting in high micronucleus formation through division, while using D-glucan before chemotherapy can offer DNA protection and recorded significant decrease in Mn formation.

The aim of the present study was to investigate chemo-protective and radio-protective effects of D-glucan.

\section{Materials and Methods}

\section{Chemicals}

D-glucan was purchased from the Vitamin Shoppe Co., North Bergen, USA. MMC, an anticancer drug, isolated from Streptomyces Caespitosus, was purchased from Kyowa Hakko Kogyo CO. LTD. Tokyo, Japan.

\section{Radiation source}

Caesium-137 unit belonging to NCRRT was used, Atomic Energy Authority, Cairo. ${ }^{137} \mathrm{Cs}$ source offers a dose rate of $0.48 \mathrm{~Gy} / \mathrm{min}$ at the time of experiment.

\section{Experimental animals}

Ninety six adult male albino rats $(120 \pm 10 \mathrm{~g})$ Sprague Dawley strain were obtained from the animal farm of the Egyptian Holding Company for Biological Products and Vaccines (VACSERA), Cairo, Egypt.

\section{Experimental design}

The animals were randomly distributed into 8 equal groups, 12 rats for each. Then it categorized as follows: G1: Animals of this group neither received treatments nor exposed to radiation processing. G2: D-glucan treated group, each animal received the proper dose of D-glucan $(20 \mathrm{mg} / \mathrm{kg}$ body $\mathrm{wt})$ dissolved in distilled water by gastric intubation's using a plastic syringe with special stainless steel needle as described by Tohamy et al. (2003). G3: MMC treated group, rats received intra peritoneal (i.p.) MMC (1.5 mg/ kg body wt) suspended in saline as described by Usui et al. (1994). The administration plan was done on $8^{\text {th }}, 10^{\text {th }}$ and $12^{\text {th }}$ days, respectively. G4: $\gamma$-irradiated group, rats were exposed to fractionated whole body $\gamma$-irradiation, delivered as 2 Gy per session, up to total dose of $6 \mathrm{~Gy}$. The irradiation schedule was done at the $8^{\text {th }}$, 
$10^{\text {th }}$ and the $12^{\text {th }}$ days, respectively. G5: D-glucan+ MMC group, animals were received D-glucan as described in G2 and additionally they received MMC as described in G3. G6: D-glucan+ $\gamma$-irradiated group, animals were received Dglucan as described in $\mathrm{G} 2$ as well as they subjected to whole body $\gamma$-irradiation as described in G4. G7: MMC+ $\gamma$-irradiated group, rats were subjected to whole body $\gamma$-irradiation as described in G4 consistent with MMC treatments as described in G3. G8: D-glucan+ MMC+ $\gamma$-irradiated group, rats were received D-glucan as described in G2, meantime, they subjected to both MMC treatment and $\gamma$-irradiation exposure as described in G3 and G4, respectively.

\section{Collection of samples}

Experimental observations were performed at two different time intervals. The first time interval was done three days after ceasing of MMC \& $\gamma$ - irradiation processing. While the second time interval was done ten days after termination of all kind of treatments. Six rats from different animal groups were sacrificed at each time interval. Blood and femoral bone marrow samples were obtained from the experimental animals following normal laboratory procedures and stored at $-20{ }^{\circ} \mathrm{C}$ until used.

\section{Determination of DNA fragmentation in blood lymphocytes}

DNA fragmentation in blood lymphocytes was determined according to the method described by Sellins and Cohen (1987) which based on the concept that extensively fragmented double-strand DNA can be separated from chromosomic DNA upon centrifugal sedimentation.

\section{Measurement of Mn Frequency}

The frequency of micronucleated erythrocytes was evaluated by a technique developed by Schmid (1976) and Feng et al. (2000). Percentage of Mn frequency was calculated as follows:

$\mathrm{Mn} \%=$ (number of cells containing Mn/ total number of cells counted) $\mathrm{x} 1000$.

\section{Statistical analysis}

The data obtained in the present work are represented in tables as mean \pm standard error. Statistical analysis was carried out using two ways analysis of variance (ANOVA) for testing the significance between various treated groups in different time intervals according to Harnett and Horrell (1998). In the 
figures, all the treated groups were compared with the control group and the differences were considered significant at $p<0.05$.

\section{Results}

\section{DNA fragmentation in lymphocytes}

Fig. 1, 2. represent black and white photograph of agarose gel, stained with ethidium bromide, under UV-irradiation at day 3 and 10, respectively. Track M represent the marker starting with 400 base pair (bp) and ends with $50 \mathrm{bp}$. Control group in track 1 showed normal DNA with no fragmentation or damage recorded as the DNA stayed in the top of the gel, same results obtained in track 2 (D-glucan treated group).

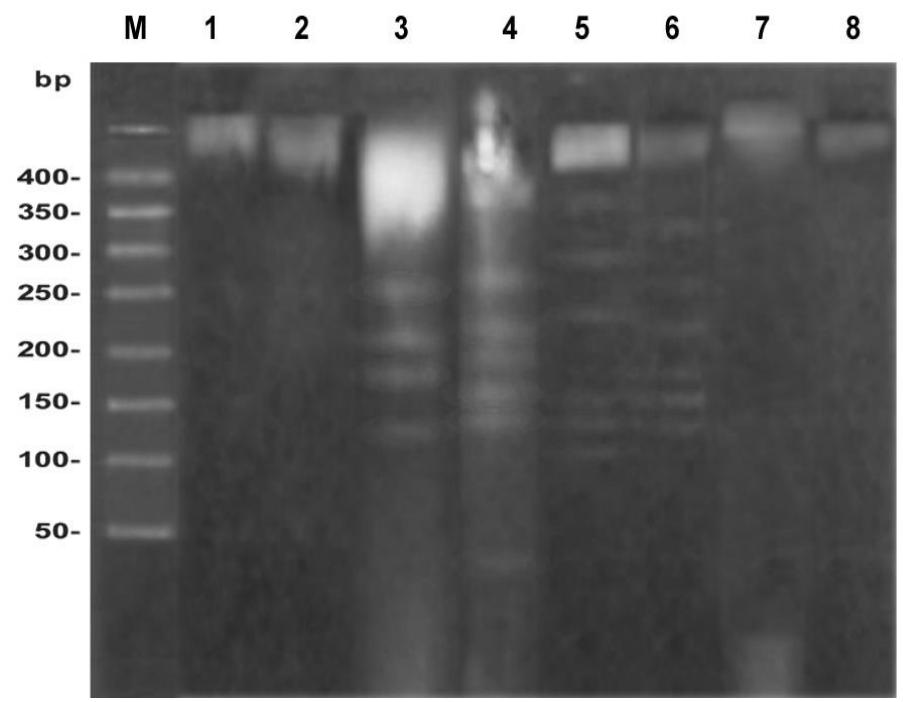

Fig. 1. Effect of D-glucan treatment on DNA fragmentation of lymphocytes in rats subjected to $\mathrm{MMC}$ and/ or $\boldsymbol{\gamma}$-irradiation at days 3 after radiation exposure.

The groups of rats receiving MMC at track 3 revealed undoubtedly apoptosis measured by DNA-fragmentation, as small fragments travelling farthest from the top to the bottom of the gel at days 3 and 10. Same results obtained in groups of animal exposed to $\gamma$-irradiation (track 4) showed complete degradation and damage of the DNA as small fragments travelled farthest on the gel. The treatment with D-glucan before MMC and/or irradiation represented in track 5, 6 were able to reduce the MMC-induced apoptosis and protect DNA from damaged. Track 7 in Fig. 1, 2. represent DNA fragments 
from group of rats treated with both MMC and then exposed to $\gamma$-irradiation at $3^{\text {rd }}$ and $10^{\text {th }}$ day post-irradiation. This track showed little amount of DNA obtained due to depletion of white blood cells (WBCs) and lymphocytes as a result of combination treatments. On the other hand, track 8 represent quite amelioration in DNA fragmentation recorded after D-glucan administration.

Black and white photograph of an agarose gel, stained with ethidium bromide, under UV-irradiation (Track M): represents the marker. (Track 1): control, (Track 2): D-glucan treated group (Track 3): MMC treated group (Track 4): $\gamma$-ray irradiated group (Track 5): groups treated with D-glucan before MMC (Track 6): groups of animal treated with D-glucan before $\gamma$-irradiated (Track 7): groups of animal exposed to both MMC then irradiation (Track 8): groups of animal treated with D-glucan before exposure to both MMC and irradiation. Samples that have migrated farthest (tracks 3, $4 \& 7$ ) are made up of smaller fragmented DNA than those that have remained near the top of the gel (tracks 1, 2, 5, $6 \& 8$ ) at days 3 post irradiation.

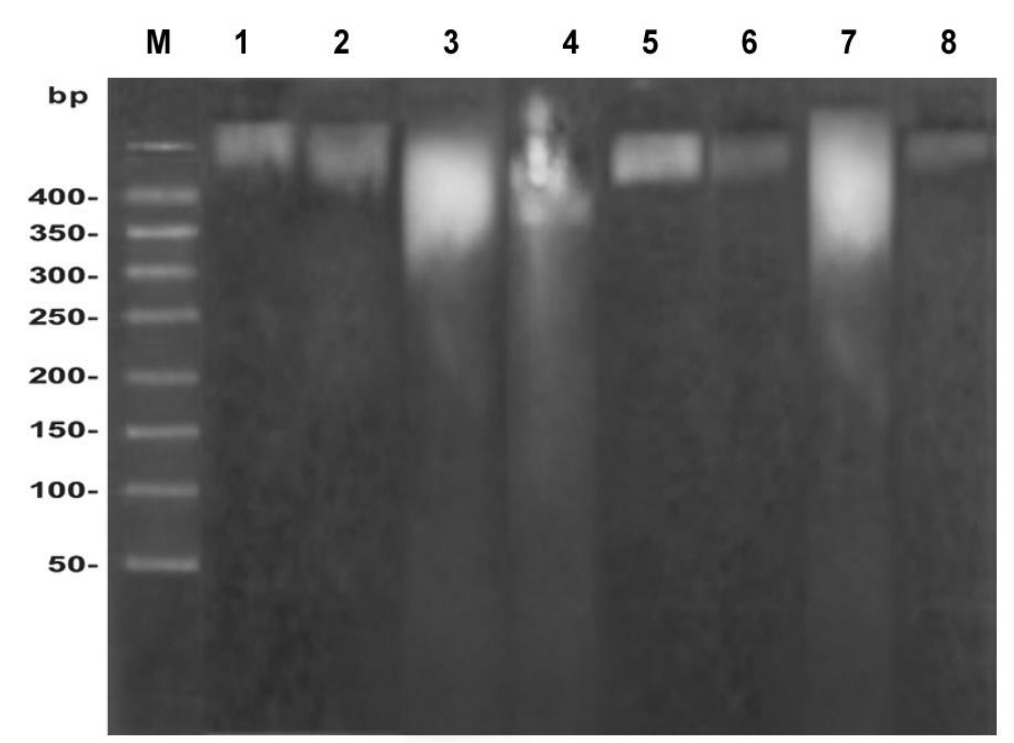

Fig. 2. Black and white photograph of an agarose gel. DNA fragmentation of rats treated with D-glucan before subjected to MMC and/ or irradiation at day 10.

As in Fig. 1. the tracks represented as a following: $M$ represents DNA fragmentation marker and tracks (1-8) represented the tested groups. According to densitometry analysis system, $\mathrm{M}$ marker ladder represented by curve with 9 Egypt. J. Rad. Sci. Applic., Vol. 26, No. 1-2 (2013) 
peaks corresponding to 9 bands of DNA fragments ranging from 400, 350, 300, $250,200,150,100,50$ and $20 \mathrm{bp}$. While, it showed one peak curve in track 1 and 2 which mean no fragmentation corresponding to control and glucan treated group. On the other hand, track 3, 4 and 7 corresponding to $\mathrm{MMC}$, irradiation and combination between both of them respectively. Each track represented with curves recorded several peaks indicating defined damage occurred in DNA. The more pronounced effect found in track 7 (MMC+ Irradiation) as the fragmentation increased. While D-glucan treatment before MMC and/ or irradiation showed significant improvement at day 10 more than day 3 .

\section{Bone marrow micronuclei frequency}

Tables 1,2. represent the effect of D-glucan treatment on Mn frequencies of rats subjected to MMC and/ or radiation exposure at the $3 \& 10$ days post irradiation.

Table. 1. Frequency of Mn in rats treated with D-glucan and subjected to MMC and/ or radiation exposure at day 3 post irradiation.

\begin{tabular}{|c|c|c|c|c|c|c|c|}
\hline Groups & \multicolumn{6}{|c|}{ Mn Frequency at day 3} & Mean \pm S.E \\
\hline G1 & $\begin{array}{c}16 / 5722 \\
2.8 \%\end{array}$ & $\begin{array}{c}14 / 5635 \\
2.48 \%\end{array}$ & $\begin{array}{c}9 / 4900 \\
1.84 \%\end{array}$ & $\begin{array}{c}10 / 5200 \\
1.92 \%\end{array}$ & $\begin{array}{c}12 / 5400 \\
2.22 \%\end{array}$ & $\begin{array}{c}11 / 4920 \\
2.24 \%\end{array}$ & $2.25 \pm 0.15$ \\
\hline G2 & $\begin{array}{c}19 / 3072 \\
6.18 \%\end{array}$ & $\begin{array}{c}13 / 3300 \\
3.94 \%\end{array}$ & $\begin{array}{c}12 / 2900 \\
4.14 \%\end{array}$ & $\begin{array}{c}14 / 4100 \\
3.41 \%\end{array}$ & $\begin{array}{c}15 / 3200 \\
4.69 \%\end{array}$ & $\begin{array}{c}11 / 3000 \\
3.6 \%\end{array}$ & $\begin{array}{c}\text { (a) } \\
4.33 \pm 0.41\end{array}$ \\
\hline G3 & $\begin{array}{l}31 / 3068 \\
10.10 \%\end{array}$ & $\begin{array}{c}19 / 2100 \\
9.05 \%\end{array}$ & $\begin{array}{c}27 / 2500 \\
9.31 \%\end{array}$ & $\begin{array}{c}23 / 2600 \\
8.08 \%\end{array}$ & $\begin{array}{c}34 / 4000 \\
8.5 \%\end{array}$ & $\begin{array}{l}38 / 3200 \\
11.88 \%\end{array}$ & $\begin{array}{c}(\mathbf{a}, \mathbf{b}) \\
9.49 \pm 0.56\end{array}$ \\
\hline G4 & $\begin{array}{l}66 / 4280 \\
15.42 \%\end{array}$ & $\begin{array}{l}60 / 4400 \\
13.64 \%\end{array}$ & $\begin{array}{l}50 / 3000 \\
16.67 \%\end{array}$ & $\begin{array}{l}55 / 3400 \\
16.18 \%\end{array}$ & $\begin{array}{l}61 / 4100 \\
14.88 \%\end{array}$ & $\begin{array}{l}59 / 4000 \\
14.75 \%\end{array}$ & $\begin{array}{c}\text { (a,b,c) } \\
15.29 \pm 0.44\end{array}$ \\
\hline G5 & $\begin{array}{c}24 / 3055 \\
7.85 \%\end{array}$ & $\begin{array}{c}25 / 3400 \\
7.35 \%\end{array}$ & $\begin{array}{c}26 / 3000 \\
8.66 \%\end{array}$ & $\begin{array}{c}19 / 2800 \\
6.79 \%\end{array}$ & $\begin{array}{c}29 / 3600 \\
8.06 \%\end{array}$ & $\begin{array}{c}21 / 3000 \\
7.00 \%\end{array}$ & $\begin{array}{c}(\mathbf{a}, \mathbf{b}, \mathbf{c}, \mathbf{d}) \\
7.62 \pm 0.61\end{array}$ \\
\hline G6 & $\begin{array}{c}31 / 3275 \\
9.47 \%\end{array}$ & $\begin{array}{c}29 / 3300 \\
8.79 \%\end{array}$ & $\begin{array}{c}22 / 2800 \\
10.3 \%\end{array}$ & $\begin{array}{c}28 / 3100 \\
9.03 \%\end{array}$ & $\begin{array}{l}29 / 2800 \\
10.30 \%\end{array}$ & $\begin{array}{c}34 / 3820 \\
8.90 \%\end{array}$ & $\begin{array}{c}(\mathbf{a}, \mathbf{b}, \mathbf{d}, \mathbf{e}) \\
9.40 \pm 0.28\end{array}$ \\
\hline G7 & $\begin{array}{l}53 / 3152 \\
16.81 \% \\
\end{array}$ & $\begin{array}{l}49 / 2600 \\
18.85 \% \\
\end{array}$ & $\begin{array}{l}50 / 3400 \\
14.70 \% \\
\end{array}$ & $\begin{array}{l}45 / 3000 \\
15.00 \% \\
\end{array}$ & $\begin{array}{l}39 / 2400 \\
16.25 \% \\
\end{array}$ & $\begin{array}{l}57 / 2900 \\
19.60 \% \\
\end{array}$ & $\begin{array}{c}\text { (a,b,c,e,f) } \\
16.87 \pm 0.81\end{array}$ \\
\hline G8 & $\begin{array}{c}29 / 2489 \\
11.65 \%\end{array}$ & $\begin{array}{c}34 / 3200 \\
10.63 \%\end{array}$ & $\begin{array}{l}24 / 2190 \\
10.96 \%\end{array}$ & $\begin{array}{l}34 / 2600 \\
13.06 \%\end{array}$ & $\begin{array}{c}21 / 2500 \\
8.40 \%\end{array}$ & $\begin{array}{l}35 / 2600 \\
13.46 \%\end{array}$ & $\begin{array}{c}\mathbf{a}, \mathbf{b}, \mathbf{c}, \mathbf{d}, \mathbf{e}, \mathbf{f}, \mathbf{g}) \\
11.36 \pm 0.75\end{array}$ \\
\hline
\end{tabular}
(a) Significant difference from control group.
(b) Significant difference from D-glucan group.
(c) Significant difference from MMC group.
(d) Significant difference from irradiated group.
(e) Significant difference from D-glucan \& MMC group
(f) Significant difference from D-glucan \& irradiated group.
(g) Significant difference from MMC \& irradiated group.

Egypt. J. Rad. Sci. Applic., Vol. 26, No. 1-2 (2013) 
The data in Table 1. revealed that, groups of rats exposed to ionizing radiation (G4) or MMC (G3) and both of them (G7), exhibited significant increase in formation of Mn comparing with control (G1). Irradiated animals (G4) recorded higher frequencies at day 3 after radiation exposure with (15.3\%) comparing with control. While groups of animals subjected to MMC alone (G3) recorded (9.5\%) and animals exposed to both MMC+ irradiation (G7) recorded the most manifested increase in Mn frequencies on day 3 with value $(16.87 \%)$ comparing with control.

D-glucan treatment before MMC (G5), before irradiation (G6) and before MMC and radiation exposure (G8) showed noticeable amelioration in their Mn frequencies comparing with corresponding groups, irradiated, MMC and combined represented in groups (G3, G4 \& G7) at day 3 post irradiation. More improvement was recorded at day 10 post irradiation. Groups of rats treated with D-glucan before MMC and/or irradiation recorded considerable decrease in $\mathrm{MN}$ frequency with value $(6.3,10.13$ and 9.93) for G5, G6 and G8 corresponding to D-glucan before MMC, D-glucan before irradiation and D-glucan before combination.

Table 2. Frequency of Mn in rats treated with D-glucan and subjected to MMC and/ or radiation exposure at day 10 post radiation.

\begin{tabular}{|c|c|c|c|c|c|c|c|}
\hline Groups & \multicolumn{6}{|c|}{ Mn Frequency at day 10} & Mean \pm S.E \\
\hline \multirow{2}{*}{ G1 } & $14 / 5600$ & $7 / 4100$ & $10 / 5000$ & $9 / 4850$ & $13 / 5000$ & $10 /$ & \\
\hline & $2.50 \%$ & $1.71 \%$ & $2.00 \%$ & $1.92 \%$ & $2.60 \%$ & $2.08 \%$ & \\
\hline \multirow{2}{*}{ G2 } & $12 / 3187$ & $20 / 4050$ & $14 / 3684$ & $11 / 3290$ & $16 / 4090$ & $10 / 2600$ & \\
\hline & $3.77 \%$ & $4.94 \%$ & $3.80 \%$ & $3.34 \%$ & $3.91 \%$ & $3.85 \%$ & 22 \\
\hline \multirow{2}{*}{ G3 } & $40 / 4900$ & $38 / 4500$ & $31 / 3990$ & $42 / 4800$ & $29 / 3000$ & $33 / 2900$ & $(\mathbf{a}, \mathbf{b})$ \\
\hline & $8.16 \%$ & $8.44 \%$ & $7.77 \%$ & $8.75 \%$ & $9.67 \%$ & $11.38 \%$ & $9.03 \pm 0.54$ \\
\hline \multirow{2}{*}{ G4 } & $12 / 1017$ & $60 / 4060$ & $54 / 3100$ & $67 / 4700$ & $51 / 3900$ & $50 / 4000$ & $(\mathbf{a}, \mathbf{b}, \mathbf{c})$ \\
\hline & $11.7 \%$ & $14.78 \%$ & $17.42 \%$ & $14.26 \%$ & $13.08 \%$ & $12.50 \%$ & $13.96 \pm 0.83$ \\
\hline \multirow{2}{*}{ G5 } & $34 / 5186$ & $31 / 5000$ & $29 / 4800$ & $22 / 4050$ & $34 / 4980$ & $30 / 4500$ & $(\mathbf{a}, \mathbf{b}, \mathbf{c}, \mathbf{d})$ \\
\hline & $6.56 . \%$ & $6.20 \%$ & $6.04 \%$ & $5.43 \%$ & $6.83 \%$ & $6.67 \%$ & $6.29 \pm 0.21$ \\
\hline \multirow{2}{*}{ G6 } & $29 / 3229$ & $32 / 3050$ & $38 / 3000$ & $30 / 2940$ & $25 / 2800$ & $19 / 2000$ & $(\mathbf{a}, \mathbf{b}, \mathbf{d}, \mathbf{e})$ \\
\hline & $8.98 \%$ & $10.49 \%$ & $12.67 \%$ & $10.20 \%$ & $8.93 \%$ & $9.50 \%$ & $10.13 \pm 0.57$ \\
\hline \multirow{2}{*}{ G7 } & $26 / 2808$ & $50 / 3000$ & $30 / 2000$ & $39 / 3000$ & $42 / 2900$ & $24 / 1900$ & $(\mathbf{a}, \mathbf{b}, \mathbf{c}, \mathbf{e}, \mathbf{f})$ \\
\hline & $9.26 \%$ & $16.67 \%$ & $15.00 \%$ & $13.00 \%$ & $14.48 \%$ & $12.63 \%$ & $13.51 \pm 1.04$ \\
\hline \multirow{2}{*}{ G8 } & $29 / 3254$ & $32 / 3050$ & $30 / 3000$ & $22 / 2500$ & $27 / 2900$ & $29 / 2400$ & $(\mathbf{a}, \mathbf{b}, \mathbf{d}, \mathbf{g})$ \\
\hline & $8.91 \%$ & $10.49 \%$ & $10.00 \%$ & $8.80 \%$ & $9.31 \%$ & $12.08 \%$ & $9.93 \pm 0.51$ \\
\hline
\end{tabular}

Legends as in Table 1.

Egypt. J. Rad. Sci. Applic., Vol. 26, No. 1-2 (2013) 


\section{Discussion}

MMC cross-links complementary strands of DNA and induces monofunctional alkylation, with attachment to a single DNA strand (Tomasz and Palom 1997). MMC primarily acts as a DNA replication inhibitor, and although monofunctional alkylation is by far the most frequently observed interaction, DNA inter-strand cross-linking is considered to be the most lethal type. Previously two mechanisms were explained by which MMC is chelating DNA through cross-linking and alkylation which require chemical or enzymatic reduction of the quinine function. The primary mechanism of this process involves the $\mathrm{C}-1$ aziridine and the $\mathrm{C}-10$ carbamate groups. Second mechanism is acidic activation of MMC by which DNA alkylation can be produced (Cummings et al., 1995). In this respect the nature of MMC cytotoxicity was described as ability to induce apoptosis through sequences of signals followed DNA alkylation (Crowston et al., 2002 and Kim et al., 2003). Same effect obtained with ionizing radiation which is toxic to living cells because it induces deleterious structural changes in essential biomolecules. A significant part of the initial damage done to cells by ionizing radiation is due to formation of hydroxyl radicals, which reacts with almost all cellular components to induce oxidative damage to DNA, lipid and protein (Sterpone and Renata 2010 and Bertollo, 2010). Moreover about $80 \%$ of the total damage to DNA caused by ionizing radiations may result from radiation-induced water-derivative free radicals and secondary carbon -based radicals (Von Sonntage, 1987).

Several studies suggested that certain carbohydrate polymers, such as D-glucan may possess free radical scavenging activity, Slamenova et al. (2003). They evaluated the scavenging capacity of D-glucan, and investigated their protective effects against oxidative DNA damage induced by oxidative species which can be generated within the cells: hydroxyl radical $(\mathrm{OH} \cdot)$ and non-radical singlet oxygen $\left({ }^{1} \mathrm{O}_{2}\right)$. Finally they contributed the protective action of D-glucan to its free radical scavenging capacity. The most sensitive index of nuclear damage was the micronucleus assay (Xue et al., 1992). Testing chemicals for the ability to induce numerical or structural chromosomal damage is easily accomplished by using the micronucleus assay. In the present study, intra peritonium mitomycin injection induced a significant increase in the micronucleus formation, moreover group of rats exposed to irradiation recorded 
more damage than mitomycin injected group as irradiation represents a physical damage to DNA which consider a strong and fixed damage. The most drastic results obtained in group received MMC then exposed to irradiation (combined treatment). These results are in accordance with Tomasz and Palom (1997). In addition, the induction of MN from DNA strand breaks by MMC may be attributed to its ability to form DNA adduct and inhibit replication and to generate free radicals beside formation of highly reactive oxygen species (ROS) by MMC (Chabner and Longo, 2006). Other opinion attributed the formation of Mn after irradiation could be due to emitted photon energy that breaks chemical bonds and produce free radicals in cells. These radicals enhance the damage to DNA and other macromolecules, which increase the risk of cancer (Cherry, 2002).

Chorvatovicova et al. (1996 and 1998) and Chorvatovicova and Sandula (1995) carried out a series of experiments concerning the anti-clastogenic effect of D-glucan on animals treated with strong mutagen they confirmed the same level of protection whether injected i.p. or intra venous. Their results recorded significant reduction in $\mathrm{Mn}$ frequency in chemotherapy treated mice after D-glucan pre-treatment. Moreover, they evaluated the antimitotic activity of D-glucan by investigating the micronucleus frequency and their data showed high significant mitotic index in groups of animal treated with MMC and/or radiation exposure while significantly improved in animals pre-treated with D-glucan.

The present observations recorded that, groups of rats that received D-glucan showed significant amelioration and inhibition of Mn frequency at day 3, which was more pronounced at day 10 post irradiation. Recent studies confirmed the free radical scavenging activity of D-glucan by spin-trap electron paramagnetic resonance (Kogan et al., 2008). The possibility of D-glucan to offer some protection against the genotoxic and cytotoxic effects of chemotherapy was stated by Tohamy et al. (2003).

\section{Conclusion}

It is concluded to add foods containing D-glucan such as (yeast- barleyoats- wheat and mushroom) to our diet can be a protector against the hazardous effects produced from environmental oxidative stress. Moreover, it could be used as a prophylactic agent against the damaging effects before starting /or during chemotherapeutic regimen.

Egypt. J. Rad. Sci. Applic., Vol. 26, No. 1-2 (2013) 


\section{References}

Bertollo, M. C. (2010) Effect of radiation treatment on newly established human breast cancer cell lines MACL-1 and MGSO-3. Tumor Biol., 31, 189.

Bobeck, P. and Calbavy, S. (2001) Effect of pleuran (beta 1,3 D-glucan from Pleurotus) on the antioxidant status of the organism and dimethylhydrazine induced precancerous lesions in rat colon. Br. J. Biomed. Sci., 58, 164.

Chabner, B. A. and Longo, D. L. (2006) In cancer chemotherapy and biotherapy. 4 th Ed. Chapter 16, Lippincott Williams \& Wilkins. p. 361.

Chen, J. and Seviour, R. (2007) Medicinal importance of fungal beta-(1/3), (1/6) glucan. Mycolog. Res., 111, 635.

Chorvatovicova, D. and Sandula, J. (1995) Effect of carboxymethyl-chitin-glucan on cyclophosphamide induced mutagenicity. Mutat. Res., 346, 43.

Chorvatovicova, D., Machova, E. and Sandula, J. (1996) Effect of ultrasonicated carboxymethyl-chitin-glucan on cyclophosphamide induced mutagenicity. Mutat. Res., 371, 115.

Chorvatovicova, D., Machova, E. and Sandula, J. (1998) Ultrasonication: the way to achieve antimutagenic effect of carboxymethyl-chitin-glucan by oral administration. Mutat. Res., 412, 83.

Crowston, J. G., Chang, L. H., Akhar, A. N. and Khaw, P. T. (2002) Apoptosis gene expression and death receptor signalling in Mitomycin $\mathrm{c}$ treated human Tenon's capsule fibroblasts. Invest. Opthalmol. Vis. Sci., 43, 692.

Cummings, J. S., Spanswick, V. J. and Smyth, J. F. (1995) Re-evaluation of the molecular pharmacology of Mitomycin c. Eur. J. cancer, 19, 18.

Dizdaroglu, M. (1992) Measurements of radiation-induced damage in DNA at the molecular level .Int. J. Radiat .Biol., 61, 175.

Feng, S. L., Wu, D., Zhang, G. D. and Kong, Z. M. (2000) Effects of two new pesticides on the micronucleus formation in mice and tadpoles. Environ. Sci. Res., 19, 137.

Harnett, D. L. and Horrell, J. F. (1998) Data, Statistics and Decision Models with Excel. John Wiley \& Sons, INC. Chapter 10, p. 450.

Kim, T., Tchah, H., Lee, S. and Kook, M. S. (2003) Mitomycin c induces apoptosis in cultured corneal fibroblasts. Invest. Ophthalamol.Vis. Sci., 44, 1912.

Kogan, G., Pajtinka, M., Babincova, M., Miadokova, E., Rauko, P., Slamenova, D. and Korolenko, T. A. (2008) Yeast cell wall polysaccharides as antioxidants and antimutagens: can they fight cancer? Neoplasma, 55, 387.

Mussari, S., Sabino Della Sala, W., Busana, L., Vanoni, V., Eccher, C., Zani, B., Menegotti, L. and Tomio, L. (2006) Full-dose intraoperative radiotherapy with electrons in breast cancer: First report on late toxicity and cosmetic results from a single-institution experience. Strahlenther Onkol., 182, 589.

Egypt. J. Rad. Sci. Applic., Vol. 26, No. 1-2 (2013) 
Nishiyama, M., Suzuki, K. and Kumazaki, T. (1997) Molecular targeting of Mitomycin c chemotherapy. Int. J. Cancer, 72, 649.

Shmakova, N. L., Nasonova, E. A., Krasavin, E. A., Mel nikova, L. A. and Fadeeva, T. A. (2006) Induction of chromosome aberrations and micronuclei in human peripheral blood lymphocytes at low dose of radiation. Radiat. Biol. Radioecol., 46, 480.

Schmid, W. (1976) the micronucleus test for cytogenetic analysis. In chemical mutagens. Principles and methods for their detection. Hollander A, 4, 31 .

Sellins, K. S. and Cohen, J. J. (1987) Gene Induction by $\gamma$-Irradiation Leads to DNA Fragmentation in Lymphocytes. J. Immunol., 139, 319.

Siddique, Y. H. and Afzal, M. (2005) Antigenotoxic effect of allicin against methylmethane sulphonate induced genotoxic damage. Environ. Biol., 26, 547.

Salmenova, D., Labaj, J., Krizkova, L., Kogan, G., Bresgen, N. and Eckl, P. (2003) Protective effects of fungal (1--- 3) D-glucan derivatives against oxidative DNA lesions in V79 hamster lung cells. Cancer Letters, 198, 153.

Stahnke, K., Fulda, S., Friesen, C., Strauss, G. and Debatin, K. (2001) Activation of apoptosis pathways in peripheral blood lymphocytes by in vivo chemotherapy, Blood J., 98, 3066.

Sterpone, S. and Renata, R. (2010) Influence of XRCC1 genetic polymorphisms on ionizing radiation induced DNA damage and repair. J. Nucleic Acid, 25, 2010.

Tohamy, A. A., El-Ghor, A. A., El-Nahas, S. M. and Nohy, M. M. (2003) $\beta$-Glucan inhibits the genotoxicity of cyclophosphamide, adriamycin and cisplatin. Mutat. Res., 541, 45.

Tomasz, M. and Palom, Y. (1997) The Mitomycin bioreductive antitumor agents cross-linking and alkylation of DNA as the molecular basis of their activity. Pharmacol. Ther., 76, 73.

Tomasz, M., Lipman, R. and Chowdary, D. (1987) Isolation and structure of covalent cross-link adduct between mitomycin c and DNA. Science, 235, 1204.

Usui, S., Murashima, K., Sakai, M., Kiho, T. and Ukai, S. (1994) Preparation and antitumor activities of mitomycin C beta-(1-->6)-branched (1-->3)-beta-Dglucan conjugate. Biol. Pharm. Bull., 17, 1165.

Von Sonntage, C. (1987) The chemical basis of radiation biology. Taylor and Francis, London.

Xue, K. X., Ma, G. J., Wang,S. and Wang, Y. P. (1992) Nuclear anomaly test in human lymphocytes in vitro. Jiangsu Instit. Cancer Res., 13, 464.

(Received: 03/03/2013;

accepted: 25/03/2013)

Egypt. J. Rad. Sci. Applic., Vol. 26, No. 1-2 (2013) 


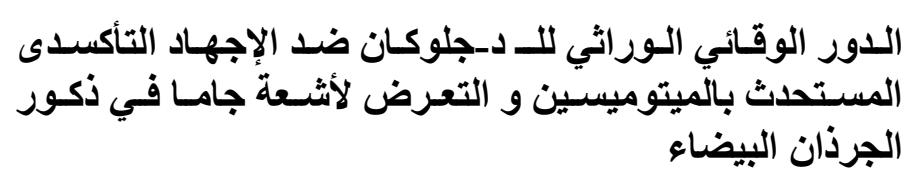

محمود محمد أحمد و نادية محمد البيه* و شيرين عبد الوهاب منتصر

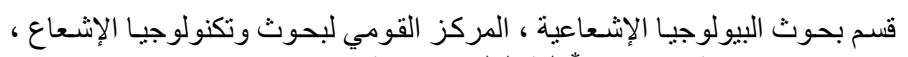

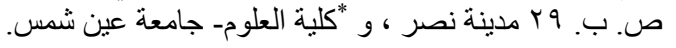

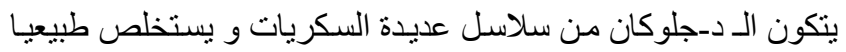

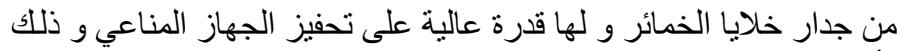

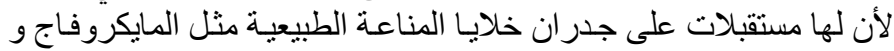
النيتروفيل و الخلايا الطبيعية المقاتلة.

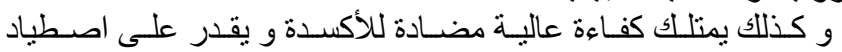

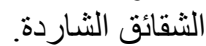

الهدف من الدر اسة تقييم الـ دـجلوكان كو اقي من التعرض الكيميائي و

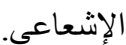

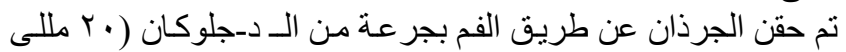

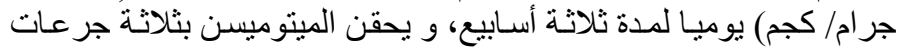

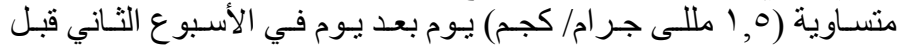

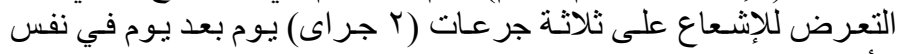

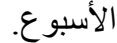

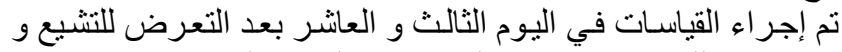

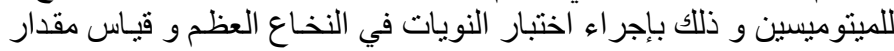
التكسير في الدنا في خلايا الدم الليمفاوية.

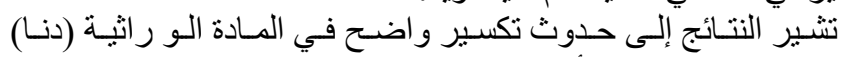

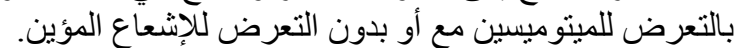

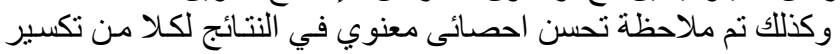

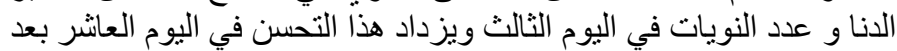

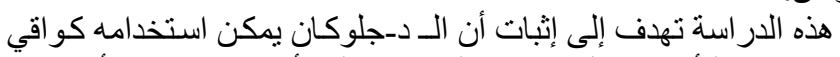

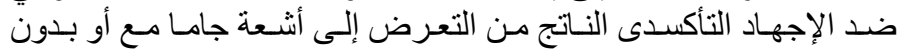

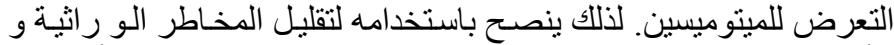

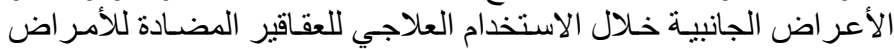

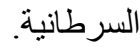

Egypt. J. Rad. Sci. Applic., Vol. 26, No. 1-2 (2013) 